\title{
\$ IODP
}

\section{Proceedings of the International Ocean Discovery Program}

\section{Volume 353}

\section{Indian Monsoon Rainfall}

Expedition 353 of the riserless drilling platform

from and to Singapore

Sites U1443-U1448

29 November 2014-29 January 2015

\section{Volume authorship}

Clemens, S.C., Kuhnt, W., LeVay, L.J., and the Expedition 353 Scientists
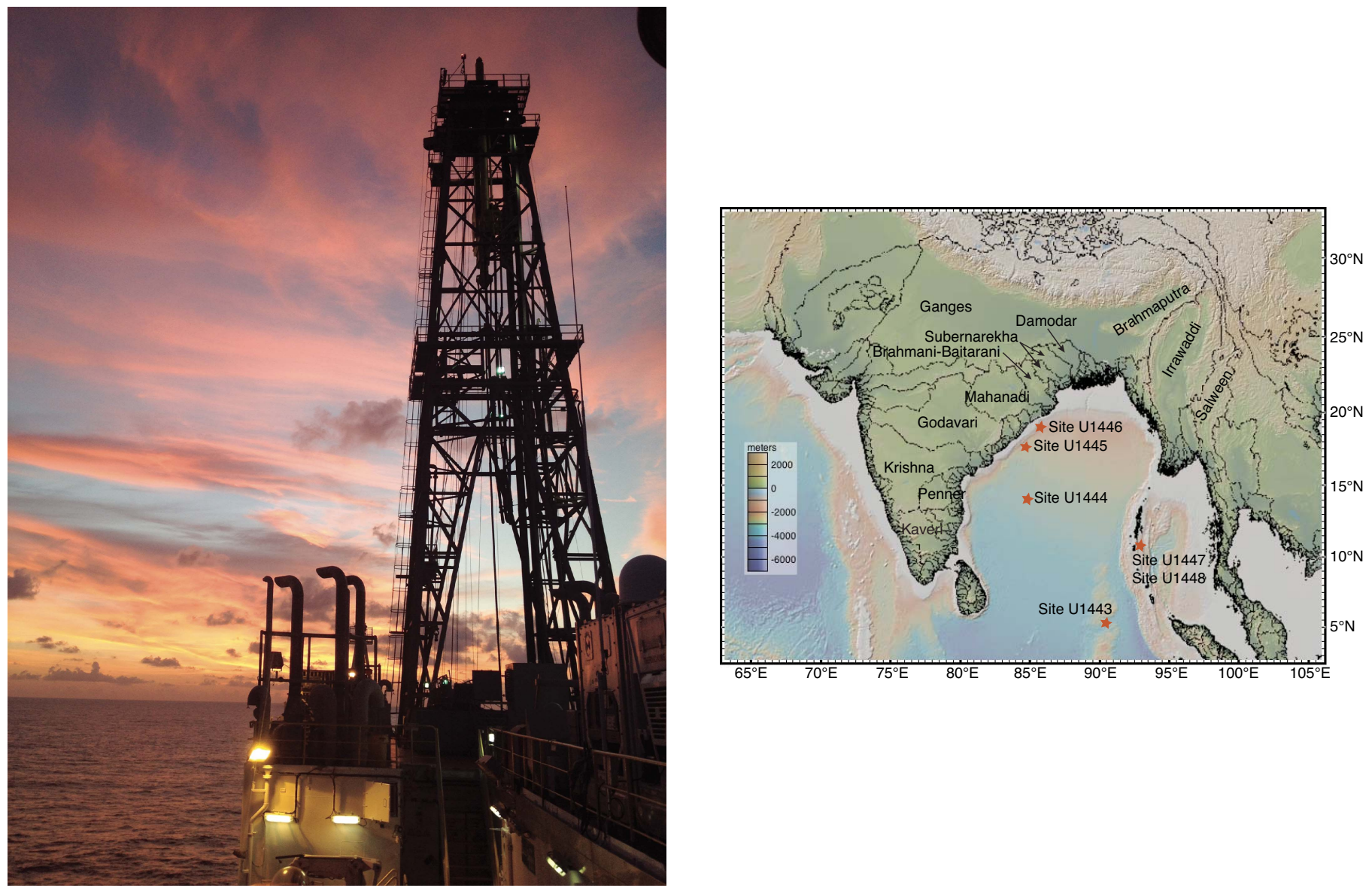

Published by

International Ocean Discovery Program 


\section{Publisher's notes}

This publication was prepared by the JOIDES Resolution Science Operator (JRSO) at Texas A\&M University (TAMU) as an account of work performed under the International Ocean Discovery Program (IODP). Funding for IODP is provided by the following international partners:

National Science Foundation (NSF), United States

Ministry of Education, Culture, Sports, Science and Technology (MEXT), Japan

European Consortium for Ocean Research Drilling (ECORD)

Ministry of Science and Technology (MOST), People's Republic of China

Korea Institute of Geoscience and Mineral Resources (KIGAM)

Australia-New Zealand IODP Consortium (ANZIC)

Ministry of Earth Sciences (MoES), India

Coordination for Improvement of Higher Education Personnel, Brazil (CAPES)

Any opinions, findings, and conclusions or recommendations expressed in this publication are those of the author(s) and do not necessarily reflect the views of the participating agencies, TAMU, or Texas A\&M Research Foundation.

The bulk of the shipboard-collected core data from this expedition is accessible at http://iodp.tamu.edu/database/index.html. If you cannot access this site or need additional data, please contact Data Librarian, International Ocean Discovery Program JOIDES Resolution Science Operator, Texas A\&M University, 1000 Discovery Drive, College Station TX 77845-9547, USA. Tel: (979) 845-8495; Fax: (979) 458-1617; Email: database@iodp.tamu.edu.

A complete set of the logging data collected during the expedition is available at http://brg.ldeo.columbia.edu/logdb. If you have problems downloading the data, wish to receive additional logging data, or have questions regarding the data, please contact Database Administrator, Borehole Research Group, Lamont-Doherty Earth Observatory of Columbia University, PO Box 1000, 61 Route 9W, Palisades NY 10964, USA. Tel: (845) 365-8343; Fax: (845) 365-3182; Email: logdb@ldeo.columbia.edu.

Supplemental data were provided by the authors and may not conform to IODP publication formats.

Some core photographs have been tonally enhanced to better illustrate particular features of interest. High-resolution images are available upon request.

Cover photograph shows the R/V JOIDES Resolution derrick at sunset. Photo credit: IODP JRSO. JRSO expedition photos are the property of IODP and are in the public domain.

\section{Copyright}

Except where otherwise noted, this work is licensed under a Creative Commons Attribution License (http://creativecommons.org/licenses/by/3.0/deed.en_US). Unrestricted use, distribution, and reproduction are permitted, provided the original author and source are credited.

Examples of how to cite this volume or part of this volume are available at http://publications.iodp.org/proceedings/353/353title.html\#bib.

\section{ISSN}

World Wide Web: 2377-3189

\section{Publication date}

29 July 2016 


\section{Contents}

\section{Expedition reports}

\section{Chapters}

Expedition 353 summary

S.C. Clemens et al.

Expedition 353 methods

S.C. Clemens et al.

Site U1443

S.C. Clemens et al.

Site U1444

S.C. Clemens et al.

Site U1445

S.C. Clemens et al.

Site U1446

S.C. Clemens et al.

Site U1447

S.C. Clemens et al.

Site U1448

S.C. Clemens et al.

Biostratigraphic summary

M.M. Robinson et al.

\section{Core descriptions}

Visual core descriptions (VCDs), smear slides, and thin sections are combined into PDF files for each site. The entire set of core images in PDF is available in the IMAGES directory.

Site U1443

Visual core descriptions $\cdot$ Smear slides $\cdot$ Thin sections

Site U1444

Visual core descriptions $\cdot$ Smear slides $\cdot$ Thin sections

Site U1445

Visual core descriptions $\cdot$ Smear slides

\section{Site U1446}

Visual core descriptions $\cdot$ Smear slides

Site U1447

Visual core descriptions $\cdot$ Smear slides

Site U1448

Visual core descriptions $\cdot$ Smear slides $\cdot$ Thin sections

\section{Supplementary material}

Supplementary material for the Volume 353 expedition reports includes a high-resolution downhole logging figure in PDF and stratigraphic correlation data in KaleidaGraph. A full list of directories can be found in SUPP_MAT in the volume zip folder or on the Supplementary material for Volume 353 expedition reports web page.

\section{Expedition research results}

\section{Data reports}

Titles are available in HTML.

\section{Syntheses}

Titles are available in HTML.

\section{Drilling location maps}

A site map showing the drilling locations for this expedition and maps showing the drilling locations of all International Ocean Discovery Program (IODP), produced using QGIS (http://www.qgis .org), Integrated Ocean Drilling Program, Ocean Drilling Program (ODP), and Deep Sea Drilling Project (DSDP), produced using Generic Mapping Tools (GMT) of Paul Wessel and Walter H.F. Smith (http://gmt.soest.hawaii.edu), are available in PDF.

IODP Expedition 353 site map

IODP map (Expeditions 349-353)

Integrated Ocean Drilling Program map (Expeditions 301-348)

ODP map (Legs 100-210)

DSDP map (Legs 1-96)

\section{Acknowledgments}

Expedition 353 was carried out by the International Ocean Discovery Program (IODP). We thank IODP for their dedication to the promotion and conduct of earth science. We thank the captain and crew of the R/V JOIDES Resolution for exceptional support at sea. We also thank the shipboard laboratory technicians for their exceptional attitude and hard work. The advice and counsel of Tim Collett, John Farrell, and Manik Talwani were invaluable; we thank them for their guidance and support prior to and during the expedition. We thank Dr. John Holdren, Director of the White House Office of Science and Technology Policy, for his efforts at the U.S.-India Joint Commission Meeting in November of 2014, which paved the way for this expedition. The expedition itself would not have been successful without the dedicated efforts of Marie Heglund, Sam Kotis, and George Sibley at the office of Environment, Science, and Technology Affairs, U.S. Embassy, New Delhi, India. The support and efforts of Dr. Milind Wakdikar and Dr. Vijay Kumar at the Ministry of Earth Sciences, New Delhi, were also crucial to our success, and we thank them. 


\section{Foreword}

The International Ocean Discovery Program (IODP) represents the latest incarnation of almost five decades of scientific ocean drilling excellence and is generally accepted as the most successful international collaboration in the history of the Earth sciences. IODP builds seamlessly on the accomplishments of previous phases: the Deep Sea Drilling Project, Ocean Drilling Program, and Integrated Ocean Drilling Program. The 2013-2023 IODP Science Plan (Illuminating Earth's Past, Present, and Future) defines four themes and thirteen challenges for this decade of scientific ocean drilling that are both of fundamental importance in understanding how the Earth works and of significant relevance to society as the Earth changes, at least in part in response to anthropogenic forcing. This phase of IODP represents a renewed level of international collaboration in bringing diverse drilling platforms and strategies to increasing our understanding of climate and ocean change, the deep biosphere and evolution of ecosystems, connections between Earth's deep processes and surface manifestations, and geologically induced hazards on human timeframes.

The Proceedings of the International Ocean Discovery Program presents the scientific and engineering results of IODP drilling projects, expedition by expedition. As in the preceding Integrated Ocean Drilling Program, expeditions in the new IODP are conducted by three implementing organizations, each providing a different drilling capability. These are the US Implementing Organization (USIO; through September 2014) and the JOIDES Resolution Science Operator (JRSO; as of October 2014), providing the leased commercial vessel JOIDES Resolution for riserless drilling operations; JAMSTEC's Center for Deep Earth Exploration (CDEX), providing the drillship Chikyu for riser and occasional riserless operations; and the European Consortium for Ocean Research Drilling (ECORD) Science Operator (ESO), providing "mission-specific" platforms (MSPs) for expeditions that extend the IODP operational range where neither drillship is suitable, for example, in polar environments and in shallow waters. Scheduling decisions for each capability are made by three independent Facility Boards, each of which includes scientists, operators, and platform funding partners: the JOIDES Resolution Facility Board (JRFB), Chikyu IODP Board (CIB), and ECORD Facility Board (EFB). At the beginning of the new IODP, the three Facility Boards agreed to utilize Publication Services at the USIO and now the JRSO for production of all expedition Proceedings volumes and reports.

The new IODP differs from prior scientific ocean drilling programs in that it has neither a central management organization nor commingled funding for program-wide activities. Yet, this phase of IODP retains a fundamental integrative structural element: a "bottom-up" evaluation of all proposals for drilling expeditions by a single advisory structure composed of scientists representing all international program partners. International scientists may submit drilling proposals to the Science Support Office; all submitted proposals are then evaluated by a Science Evaluation Panel in the context of the Science Plan.

The new IODP also has a second internationally integrative level for high-level discussion and consensus-building: the IODP Forum. The Forum is charged with assessing program-wide progress toward achieving the Science Plan. At present, IODP involves 26 international financial partners, including the United States, Japan, an Australia/New Zealand consortium (ANZIC), Brazil, China, India, South Korea, and the eighteen members of ECORD (Austria, Belgium, Canada, Denmark, Finland, France, Germany, Ireland, Israel, Italy, the Netherlands, Norway, Poland, Portugal, Spain, Sweden, Switzerland, and the United Kingdom). This enhanced membership in the new IODP represents a remarkable level of international collaboration that remains one of the greatest ongoing strengths of scientific ocean drilling.

James A. Austin, Jr. Chair, IODP Forum 


\section{International Ocean Discovery Program}

\section{JOIDES Resolution Science Operator}

Website: http://iodp.tamu.edu

\section{IODP JRSO}

International Ocean Discovery Program

Texas A\&M University

1000 Discovery Drive

College Station TX 77845-9547

USA

Tel: (979) 845-2673; Fax: (979) 845-4857

Email: information@iodp.tamu.edu
IODP JRSO Curation and Laboratories

IODP Gulf Coast Repository (GCR)

Texas A\&M University

1000 Discovery Drive

College Station TX 77845-9547

USA

Tel: (979) 845-8490; Fax: (979) 845-1303

Email: rumford@iodp.tamu.edu

\section{European Consortium for Ocean Research Drilling, Science Operator (ESO)}

Website: http://www.eso.ecord.org

IODP ESO Coordinator: Science, Logistics, and Operations

British Geological Survey

The Lyell Centre

Research Avenue South

Edinburgh EH14 4AP

United Kingdom

Tel: (44) 131-667-1000; Fax: (44) 131-668-4140

Email: eso@bgs.ac.uk

IODP ESO Petrophysics

European Petrophysics Consortium

Department of Geology

University of Leicester

Leicester LE1 7RH

United Kingdom

Tel: (44) 116-252-3611; Fax: (44) 116-252-3918

Email: sjd27@leicester.ac.uk

\section{IODP ESO Curation and Laboratories}

IODP Bremen Core Repository (BCR)

Center for Marine Environmental Sciences (MARUM)

University of Bremen

Leobener Strasse

28359 Bremen

Germany

Tel: (49) 421-218-65560; Fax: (49) 421-218-98-65560

Email: bcr@marum.de

\section{Japan Agency for Marine-Earth Science and Technology (JAMSTEC)}

Website: http://www.jamstec.go.jp/chikyu/e

\section{IODP Japan Science Operator}

Center for Deep Earth Exploration (CDEX)

Japan Agency for Marine-Earth Science and Technology

Yokohama Institute for Earth Sciences

3175-25 Showa-machi

Kanazawa-ku, Yokohama

Kanagawa 236-0001

Japan

Tel: (81) 45-778-5643; Fax: (81) 45-778-5704

Email: cdex@jamstec.go.jp

\section{IODP Japan Curation and Laboratories}

IODP Kochi Institute for Core Sample Research (KCC) Japan Agency for Marine-Earth Science and Technology 200 Monobe Otsu

3175-25 Showa-machi

Nankoku City, Kochi 783-8502

Japan

Tel: (81) 88-864-6705; Fax: (81) 88-878-2192

Email: kcc.contact@jamstec.go.jp 


\section{Expedition 353 participants*}

\section{Expedition 353 scientists}

\section{Steven C. Clemens}

Co-Chief Scientist

Department of Earth, Environmental, and Planetary Sciences

Brown University

324 Brooks Street

Providence RI 02912-1846

USA

steven_clemens@brown.edu

\section{Wolfgang Kuhnt}

Co-Chief Scientist

Institut für Geowissenschaften

Christian-Albrechts-Universität zu Kiel

Ludewig-Meyn-Strasse 10-14

24118 Kiel

Germany

wk@gpi.uni-kiel.de

\section{Leah J. LeVay}

Expedition Project Manager/Staff Scientist

International Ocean Discovery Program

1000 Discovery Drive

College Station TX 77845

USA

levay@iodp.tamu.edu

\section{Pallavi Anand}

Physical Properties Specialist

Department of Earth Sciences

The Open University

Milton Keyes

MK7 6AA

United Kingdom

pallavi.anand@open.ac.uk

Takuto Ando

Sedimentologist

Hokkaido University

Department of Natural History Sciences

N10W8 Kita-ku

Sapporo 060-0810

Japan

tact@mail.sci.hokudai.ac.jp

Milos Bartol

Paleontologist (nannofossils)

Institute of Earth Sciences

Uppsala University

Villavagen 16

752036 Uppsala

Sweden

Milos.Bartol@geo.uu.se
Clara T. Bolton

Paleontologist (nannofossils)

Aix-Marseille Université, CNRS, IRD, CEREGE UM34

Europôle Méditerranéen de l'Arbois

Avenue Louis Philibert

13545 Aix en Provence

France

bolton@cerege.fr

Xuan Ding

Paleontologist (foraminifers)

Department of Marine Science and Engineering

China University of Geosciences

29 Xue Yuan Road

Haidian District

Beijing

China

dingx@cugb.edu.cn

Karen Gariboldi

Paleontologist (diatoms)

Dipartimento di Scienze della Terra

Università degli Studi di Pisa

Via Santa Maria 53

56126 Pisa

Italy

karen.gariboldi@for.unipi.it

Liviu Giosan

Stratigraphic Correlator

Department of Geology and Geophysics

Woods Hole Oceanographic Institution

266 Woods Hole Road, MS 22

Woods Hole MA 02543

USA

lgiosan@whoi.edu

Ed C. Hathorne

Inorganic Geochemist

GEOMAR Helmholtz Centre for Ocean Research Kiel

Wischhofstrasse 1-3

24148 Kiel

Germany

ehathorne@geomar.de

Yongsong Huang

Organic Geochemist

Department of Earth, Environmental, and Planetary Sciences

Brown University

324 Brooks Street

Providence RI 02912-1846

USA

yongsong_huang@brown.edu

*Addresses at time of expedition, except where updated by participants. 
Priyank Jaiswal

Downhole Tools Specialist/Physical Properties Specialist

Boone Pickens School of Geology

Oklahoma State University

105 Noble Research Center

Stillwater OK 74075

USA

priyank.jaiswal@okstate.edu

\section{Sunghan Kim}

Sedimentologist

Busan National University

Department of Oceanography

Busan 609-735

Republic of Korea

delongksh@pusan.ac.kr

John B. Kirkpatrick

Inorganic Geochemist

Graduate School of Oceanography

University of Rhode Island

215 South Ferry Road

Narragansett RI 02882

USA

jbk@gso.uri.edu

\section{Kate Littler}

Sedimentologist

Camborne School of Mines

University of Exeter

Penryn Campus

Cornwall TR10 9FE

United Kingdom

k.littler@exeter.ac.uk

\section{Gianluca Marino}

Stratigraphic Correlator

Research School of Earth Sciences

The Australian National University

Building 124 Mills Road

Canberra ACT 2601

Australia

gianluca.marino@anu.edu.au

\author{
Philippe Martinez \\ Sedimentologist \\ University of Bordeaux \\ UMR CNRS 5805 EPOC \\ Allee Geoffroy de Saint Hilaire \\ 33615 Pessac \\ France \\ philippe.martinez@u-bordeaux.fr
}

Dinesh Naik (boarded 30 December 2014)

\section{Sedimentologist}

Geological Oceanography Division

National Institute of Oceanography

Dona Paula

Goa 403004

India

dnaik@nio.org
Aditya Peketi (boarded 30 December 2014)

Inorganic Geochemist

Geological Oceanography Division

National Institute of Oceanography

Dona Paula

Goa 403004

India

aditya@nio.org

Stephen C. Phillips

Sedimentologist

Department of Earth Sciences

University of New Hampshire

214 James Hall

56 College Road

Durham NH 03824

USA

phillips.stephen.c@gmail.com

Marci M. Robinson

Paleontologist (foraminifers)

Eastern Geology and Paleoclimate Science Center

United States Geological Survey

926A National Center

12201 Sunrise Valley Drive

Reston VA 20192

USA

mmrobinson@usgs.gov

Oscar E. Romero

Paleontologist (diatoms)

MARUM

University of Bremen

Leobenerstrasse

28359 Bremen

Germany

oromero@uni-bremen.de

Netramani Sagar (boarded 30 December 2014)

Inorganic Geochemist

Geochemistry Division

National Geophysical Research Institute (NGRI)

Uppal Road

Hyderabad Andhra

Pradesh 500007

India

n.sagar@ngri.res.in

Katie B. Taladay

Downhole Tools Specialist/Physical Properties Specialist

Department of Geology and Geophysics SOEST

University of Hawaii at Manoa

POST Building, Room 813

1680 East-West Road

Honolulu HI 96822

USA

taladay@hawaii.edu 
Samuel N. Taylor

Paleomagnetist

Institut de Physique du Globe de Paris

1 Rue Jussieu

75238 Paris

France

taylor@ipgp.fr

Kaustubh Thirumalai

Sedimentologist

Institute for Geophysics

University of Texas at Austin

J.J. Pickle Research Campus

Building 196

10100 Burnet Road

Austin TX 78758-4445

USA

kau@ig.utexas.edu

\section{Goichiro Uramoto}

Sedimentologist

Kochi Institute for Core Sample Research

Japan Agency for Marine-Earth Science and Technology

B200 Monobe, Nankoku City

Kochi 783-8502

Japan

uramotog@jamstec.go.jp

Yoichi Usui

Paleomagnetist

Institute for Research on Earth Evolution

Japan Agency for Marine-Earth Science and Technology

2-15 Natsushima-cho

Yokosuka 237-0061

Japan

yoichi@jamstec.go.jp

\section{Education and outreach}

\section{Juliet Crowell}

Education Officer

Smithsonian Science Education Center

901 D Street, SW, Suite 704-B

Washington DC 20024

USA

belize67@aol.com
Jiasheng Wang

Physical Properties Specialist

Faculty of Earth Sciences

China University of Geosciences

Lumo Rodd 388

Wuhan Hubei Province

China

js-wang@cug.edu.cn

Masanobu Yamamoto

Organic Geochemist

Hokkaido University

Faculty of Environmental Earth Science

Kita-10, Nishi-5, Kita-ku

Sapporo 060-0810

Japan

myama@ees.hokudai.ac.jp

Liping Zhou

Sedimentologist

Centre for Ocean Research

Peking University

Yiheyuan Road Number 5

Beijing 100871

China

lpzhou@pku.edu.cn

\section{Operational and technical staff}

\section{Siem Offshore AS officials}

Terry Skinner

Master of the Drilling Vessel

\author{
Markus Fingerle \\ Education Officer \\ Peutinger Gymnasium (High School) \\ Peutinger Strasse 16 \\ 73479 Ellwangen/Jagst \\ Germany \\ markus.fingerle@gmx.de
}

Sam McLelland

Offshore Installation Manager 


\section{JRSO shipboard personnel and technical representatives}

Heather Barnes

Assistant Laboratory Officer

Susan Boehm

X-Ray Laboratory

Adam Bogus

Marine Laboratory Specialist (temporary)

Chad Broyles

Curatorial Specialist

Michael Cannon

Marine Computer Specialist

Colin Carney

Marine Laboratory Specialist (temporary)

Etienne Claassen

Marine Instrumentation Specialist

William Crawford

Senior Imaging Specialist

Aaron de Loach

Marine Laboratory Specialist (temporary)

Edwin Garrett

Petrophysics Laboratory

Kevin Grigar

Operations Superintendent

Margaret Hastedt

Core Laboratory

\section{IODP Publication Services staff*}

Douglas Cummings

Graphics Specialist II

Gudelia ("Gigi”) Delgado

Senior Publications Coordinator

Patrick H. Edwards

Production Specialist IV

Jaime A. Gracia

Supervisor of Production and Graphics

Jenni Hesse

Editor III

Rhonda Kappler

Graphics Specialist III

Shana C. Lewis

Editor III

Ginny Lowe

Reports Coordinator
Jon Howell

Applications Developer

Brad Julson

Laboratory Officer

Jan Jurie Kotze

Marine Instrumentation Specialist

Aaron Mechler

Marine Laboratory Specialist (temporary)

Erik Moortgat

Chemistry Laboratory

Algie Morgan

Applications Developer

Chieh Peng

Assistant Laboratory Officer

Vincent Percuoco

Chemistry Laboratory

Alyssa Stephens

Publications Specialist

Kerry Swain

Schlumberger Engineer

Steven Thomas

Marine Computer Specialist

Kevin Werts

Underway Geophysics Laboratory

Amy McWilliams

Editor IV

Angeline T. Miller

Manager of Publication Services

Lorri Peters

Supervisor of Editing

Kenneth Sherar

Production Specialist III

Alyssa Stephens

Graphics Specialist III

Crystal Wolfe

Production Specialist III

Jean Wulfson

Graphics Specialist III

Ann Yeager

Distribution Specialist

*At time of publication. 


\section{Expedition-related bibliography*}

\section{IODP publications}

\section{Scientific Prospectus}

Clemens, S.C., Kuhnt, W., and LeVay, L.J., 2014. Expedition 353 Scientific Prospectus: iMonsoon. International Ocean Discovery Program. http://dx.doi.org/10.14379/iodp.sp.353.2014

\section{Preliminary Report}

Clemens, S.C., Kuhnt, W., LeVay, L.J., and the Expedition 353 Scientists, 2015. Expedition 353 Preliminary Report: Indian Monsoon Rainfall. International Ocean Discovery Program. http://dx.doi.org/10.14379/iodp.pr.353.2015

\section{Proceedings volume}

Clemens, S.C., Kuhnt, W., LeVay, L.J., and the Expedition 353 Scientists, 2016. Indian Monsoon Rainfall. Proceedings of the International Ocean Discovery Program, 353: College Station, TX (International Ocean Discovery Program). http://dx.doi.org/10.14379/iodp.proc.353.2016

\section{Expedition reports}

Clemens, S.C., Kuhnt, W., LeVay, L.J., Anand, P., Ando, T., Bartol, M., Bolton, C.T., Ding, X., Gariboldi, K., Giosan, L., Hathorne, E.C., Huang, Y., Jaiswal, P., Kim, S., Kirkpatrick, J.B., Littler, K., Marino, G., Martinez, P., Naik, D., Peketi, A., Phillips, S.C., Robinson, M.M., Romero, O.E., Sagar, N., Taladay, K.B., Taylor, S.N., Thirumalai, K., Uramoto, G., Usui, Y., Wang, J., Yamamoto, M., and Zhou, L., 2016. Expedition 353 summary. In Clemens, S.C., Kuhnt, W., LeVay, L.J., and the Expedition 353 Scientists, Indian Monsoon Rainfall. Proceedings of the International Ocean Discovery Program, 353: College Station, TX (International Ocean Discovery Program). http://dx.doi.org/10.14379/iodp.proc.353.101.2016

Clemens, S.C., Kuhnt, W., LeVay, L.J., Anand, P., Ando, T., Bartol, M., Bolton, C.T., Ding, X., Gariboldi, K., Giosan, L., Hathorne, E.C., Huang, Y., Jaiswal, P., Kim, S., Kirkpatrick, J.B., Littler, K., Marino, G., Martinez, P., Naik, D., Peketi, A., Phillips, S.C., Robinson, M.M., Romero, O.E., Sagar, N., Taladay, K.B., Taylor, S.N., Thirumalai, K., Uramoto, G., Usui, Y., Wang, J., Yamamoto, M., and Zhou, L., 2016. Expedition 353 methods. In Clemens, S.C., Kuhnt, W., LeVay, L.J., and the Expedition 353 Scientists, Indian Monsoon Rainfall. Proceedings of the International Ocean Discovery Program, 353: College Station, TX (International Ocean Discovery Program). http://dx.doi.org/10.14379/iodp.proc.353.102.2016

Clemens, S.C., Kuhnt, W., LeVay, L.J., Anand, P., Ando, T., Bartol, M., Bolton, C.T., Ding, X., Gariboldi, K., Giosan, L., Hathorne, E.C., Huang, Y., Jaiswal, P., Kim, S., Kirkpatrick, J.B., Littler, K., Marino, G., Martinez, P., Naik, D., Peketi, A., Phillips, S.C., Robinson, M.M., Romero, O.E., Sagar, N., Taladay, K.B., Taylor, S.N., Thirumalai, K., Uramoto, G., Usui, Y., Wang, J., Yamamoto, M., and Zhou, L., 2016. Site U1443. In Clemens, S.C., Kuhnt, W., LeVay, L.J., and the Expedition 353 Scientists, Indian Monsoon Rainfall. Proceedings of the International Ocean Discovery Program, 353: College Station, TX (International Ocean Discovery Program). http://dx.doi.org/10.14379/iodp.proc.353.103.2016

Clemens, S.C., Kuhnt, W., LeVay, L.J., Anand, P., Ando, T., Bartol, M., Bolton, C.T., Ding, X., Gariboldi, K., Giosan, L., Hathorne, E.C., Huang, Y., Jaiswal, P., Kim, S., Kirkpatrick, J.B., Littler, K., Marino, G., Martinez, P., Naik, D., Peketi, A., Phillips, S.C., Robinson, M.M., Romero, O.E., Sagar, N., Taladay, K.B., Taylor, S.N., Thirumalai, K., Uramoto, G., Usui, Y., Wang, J., Yamamoto, M., and Zhou, L., 2016. Site U1444. In Clemens, S.C., Kuhnt, W., LeVay, L.J., and the Expedition 353 Scientists, Indian Monsoon Rainfall. Proceedings of the International Ocean Discovery Program, 353: College Station, TX (International Ocean Discovery Program). http://dx.doi.org/10.14379/iodp.proc.353.104.2016
Clemens, S.C., Kuhnt, W., LeVay, L.J., Anand, P., Ando, T., Bartol, M., Bolton, C.T., Ding, X., Gariboldi, K., Giosan, L., Hathorne, E.C., Huang, Y., Jaiswal, P., Kim, S., Kirkpatrick, J.B., Littler, K., Marino, G., Martinez, P., Naik, D., Peketi, A., Phillips, S.C., Robinson, M.M., Romero, O.E., Sagar, N., Taladay, K.B., Taylor, S.N., Thirumalai, K., Uramoto, G., Usui, Y., Wang, J., Yamamoto, M., and Zhou, L., 2016. Site U1445. In Clemens, S.C., Kuhnt, W., LeVay, L.J., and the Expedition 353 Scientists, Indian Monsoon Rainfall. Proceedings of the International Ocean Discovery Program, 353: College Station, TX (International Ocean Discovery Program). http://dx.doi.org/10.14379/iodp.proc.353.105.2016

Clemens, S.C., Kuhnt, W., LeVay, L.J., Anand, P., Ando, T., Bartol, M., Bolton, C.T., Ding, X., Gariboldi, K., Giosan, L., Hathorne, E.C., Huang, Y., Jaiswal, P., Kim, S., Kirkpatrick, J.B., Littler, K., Marino, G., Martinez, P., Naik, D., Peketi, A., Phillips, S.C., Robinson, M.M., Romero, O.E., Sagar, N., Taladay, K.B., Taylor, S.N., Thirumalai, K., Uramoto, G., Usui, Y., Wang, J., Yamamoto, M., and Zhou, L., 2016. Site U1446. In Clemens, S.C., Kuhnt, W., LeVay, L.J., and the Expedition 353 Scientists, Indian Monsoon Rainfall. Proceedings of the International Ocean Discovery Program, 353: College Station, TX (International Ocean Discovery Program). http://dx.doi.org/10.14379/iodp.proc.353.106.2016

Clemens, S.C., Kuhnt, W., LeVay, L.J., Anand, P., Ando, T., Bartol, M., Bolton, C.T., Ding, X., Gariboldi, K., Giosan, L., Hathorne, E.C., Huang, Y., Jaiswal, P., Kim, S., Kirkpatrick, J.B., Littler, K., Marino, G., Martinez, P., Naik, D., Peketi, A., Phillips, S.C., Robinson, M.M., Romero, O.E., Sagar, N., Taladay, K.B., Taylor, S.N., Thirumalai, K., Uramoto, G., Usui, Y., Wang, J., Yamamoto, M., and Zhou, L., 2016. Site U1447. In Clemens, S.C., Kuhnt, W., LeVay, L.J., and the Expedition 353 Scientists, Indian Monsoon Rainfall. Proceedings of the International Ocean Discovery Program, 353: College Station, TX (International Ocean Discovery Program). http://dx.doi.org/10.14379/iodp.proc.353.107.2016

Clemens, S.C., Kuhnt, W., LeVay, L.J., Anand, P., Ando, T., Bartol, M., Bolton, C.T., Ding, X., Gariboldi, K., Giosan, L., Hathorne, E.C., Huang, Y., Jaiswal, P., Kim, S., Kirkpatrick, J.B., Littler, K., Marino, G., Martinez, P., Naik, D., Peketi, A., Phillips, S.C., Robinson, M.M., Romero, O.E., Sagar, N., Taladay, K.B., Taylor, S.N., Thirumalai, K., Uramoto, G., Usui, Y., Wang, J., Yamamoto, M., and Zhou, L., 2016. Site U1448. In Clemens, S.C., Kuhnt, W., LeVay, L.J., and the Expedition 353 Scientists, Indian Monsoon Rainfall. Proceedings of the International Ocean Discovery Program, 353: College Station, TX (International Ocean Discovery Program). http://dx.doi.org/10.14379/iodp.proc.353.108.2016

Robinson, M.M., Bartol, M., Bolton, C.T., Ding, X., Gariboldi, K., Romero, O.E., and the Expedition 353 Scientists, 2016. Biostratigraphic summary. In Clemens, S.C., Kuhnt, W., LeVay, L.J., and the Expedition 353 Scientists, Indian Monsoon Rainfall. Proceedings of the International Ocean Discovery Program, 353: College Station, TX (International Ocean Discovery Program). http://dx.doi.org/10.14379/iodp.proc.353.109.2016

Supplementary material

Clemens, S.C., Kuhnt, W., LeVay, L.J., and the Expedition 353 Scientists, 2016. Supplementary material, http://dx.doi.org/10.14379/iodp.proc.353supp.2016. Supplement to Clemens, S.C., Kuhnt, W., LeVay, L.J., and the Expedition 353 Scientists, Indian Monsoon Rainfall. Proceedings of the International Ocean Discovery Program, 353: College Station, TX (International Ocean Discovery Program). http://dx.doi.org/10.14379/iodp.proc.353.2016

"The Expedition-related bibliography is continually updated online (http://publications.iodp.org/proceedings/353/353title.html\#bib). Please send updates to PubCrd@iodp.tamu.edu. 